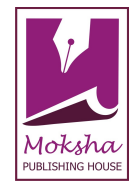

\author{
Research Article \\ www.ijrap.net
}

\title{
EVALUATION OF HELIANTHUS ANNUUS L. LEAVES EXTRACT FOR THE ANTIDIARRHEAL AND ANTIHISTAMINIC ACTIVITY
}

Dwivedi A*, Sharma GN, Kaushik AY

School of Pharmaceutical Sciences, Jaipur National University, Jaipur, Rajasthan, India

Received on: 21/10/14 Revised on: 20/12/14 Accepted on: 07/01/15

\author{
*Corresponding author \\ Dwivedi A, School of Pharmaceutical Sciences, Jaipur National University, Jaipur, Rajasthan, India \\ E-mail: dwivedi1409@hotmail.com
}

DOI: $10.7897 / 2277-4343.06125$

\begin{abstract}
The objective of this study was to evaluate the anti diarrheal and antihistaminic activity of ethanolic extract of the leaves of Helianthus annuus L. at the dose of $250 \mathrm{mg} / \mathrm{kg}$ and $500 \mathrm{mg} / \mathrm{kg}$ body weight using castor oil induced diarrhoea and gastrointestinal transit model for anti diarrheal activity and histamine induced bronchoconstriction on guinea pigs and microshock model on rabbits for antihistaminic activity. At various doses (250 and $500 \mathrm{mg} / \mathrm{kg}$ body weight), the extract showed a remarkable antioxidant activity when compared to ascorbic acid. Results also confirmed that Helianthus annuus L. decreases the severity of diarrhoea and possess the anti-histaminic potential to treat the allergic disorders.
\end{abstract}

Keywords: Sunflower, Diarrhea, Histamine, Castor oil.

\section{INTRODUCTION}

Sunflower (Helianthus annuus L.) is famous for its unique nature of heliotropism and is the world's second most important source of edible oil. Helianthus annuus L. is a folk remedy for several diseases such as; bronchitis, cough, diarrhea, dysentery, fever, flu, inflammations, laryngitis, malaria, menorrhagia, pleuritis, rheumatism, scorpion stings, snakebite, splenitis, wounds etc. ${ }^{1}$ Helianthus annuus L. contains carbohydrates, flavonoids, tannins, alkaloids, saponins, phytosterols, steroids and fixed oils ${ }^{2}$ and the leaves of this plant have these contents more than other parts ${ }^{3}$. It also has efficient quantities of antioxidants like tocopherols etc. to produce free radical scavenging activity. ${ }^{4}$ Several research studies were carried out to find out the different pharmacological activity on the different parts of the Helianthus annuus L. like; antidiabetic, antitumor, antioxidant, anti asthmatic, anti-inflammatory, hypolipidemic and antibacterial activity. ${ }^{5-11}$ As we know diarrhea is very common gastric problem which occurs due to low gastric motility, low water absorption, microbial infection etc. and might be fatal, if not controlled. ${ }^{12}$ Histamine is an organic nitrogenous compound release in body and involved in all inflammatory and allergic diseases. ${ }^{13}$ On the basis of its traditional uses and active constituents like; flavonoids, alkaloids, phenols etc. ${ }^{14}$, leaves of this plant can be utilized to evaluate anti diarrheal as well as antihistaminic activity due to its high phytoconstituent concentration. ${ }^{15}$

\section{MATERIAL AND METHODS \\ Collection and authentication of plant material}

The leaves of the Helianthus annuus L. were collected in the month of October from the Smriti Forest, Jaipur, Rajasthan, India. The plants were authenticated by the taxonomist from Department of Botany, University of
Rajasthan, Jaipur, Rajasthan, India. The herbarium voucher specimen number was (RUBL.20711) submitted to the institute wherein the study was carried out.

\section{Chemicals and standard drugs}

Ethanol (solvent for extraction), Castor oil (laxative agent), DPPH, Ascorbic acid (standard antioxidant), Histamine, Loparamide (standard reference anti diarrheal drug), Atropine sulphate (standard reference anti diarrheal drug) and Chlorpheniramine maleate (standard reference antihistaminic drug) were used.

\section{Preparation of plant extract}

Leaves of plant Helianthus annuus L. were shade dried at room temperature. Leaves were reduced to coarse powder and passed through a 40 no. sieve to obtain desired particle size. The coarse powder of the Helianthus annuus L. leaves $(100 \mathrm{~g})$ were extracted with the $95 \%$ ethanol by cold maceration process for period of 72 hours into the conical flask. ${ }^{16}$ The filtrate obtained was evaporated to dryness.

$$
\% \text { yield }=(\text { weight } \text { of extract } / \text { weight of dried powder }) \times 100
$$

\section{Phytochemical screening}

Standard screening test of the extract was carried out for various plant constituents. The crude extract was screened for the presence or absence of secondary metabolites such as alkaloids, carbohydrate, phenolic compounds, flavonoids, saponins, steroids, tannins, etc. by using standard procedures. ${ }^{17}$ 


\section{In-vitro antioxidant activity using DPPH as standard}

The stable radical DPPH has been used widely for the determination of primary anti-oxidant activity. DPPH, after accepting electron or hydrogen radical, is converted into stable DPPH-H form. When this conversion occurs, deep violet color of DPPH turns into light yellow color. Unconverted DPPH is detected by UV spectrophotometer at $517 \mathrm{~nm}$ against blank and percent inhibition was calculated. Free radical scavenging activity of the ethanol extracts was substantiated by DPPH assay. Sample was prepared in ethanol at different concentrations of 500, $200,100,50,10,5$, and $1 \mu \mathrm{g} / \mathrm{ml}$. Sample of $1 \mathrm{ml}$ of each concentration was added to $3 \mathrm{ml}$ of $0.004 \%$ ethanol solution of DPPH. Incubation period of 30 min was allowed at room temperature in dark place to complete any reaction that is to be occurred. Then absorbance was measured by UV spectrophotometer at $517 \mathrm{~nm}$ against blank. Ascorbic acid was used as standard free radical scavenger and activity of the extract was compared with it. $^{18}$

Activity of the sample was calculated from [(A1-A2)/A1] x100,

Where, A1 is the absorbance of the control and A2 is the absorbance of the standard/ sample extract

\section{Castor oil induced diarrhea model}

The mice of weight 20-25 g were divided in to the four groups with four animals in each group and were housed in labeled cages. Animals were given a period of time to adjust to the new environment provided with food and water. The Group I Animal were administered the $0.1 \mathrm{ml}$ saline. Group II Animals received the reference standard drug loperamide (3 $\mathrm{mg} / \mathrm{kg}$ body weight). Group III Animals were given ethanolic extract of Helianthus annuus L. at dose of $250 \mathrm{mg} / \mathrm{kg}$ body weight. Group IV Animals were given ethanolic extract of Helianthus annuus L. at dose of $500 \mathrm{mg} / \mathrm{kg}$ body weight. All animals were fasted for $24 \mathrm{~h}$ before the administration of drugs. After 60 minute of administration of doses each animal were feed $2 \mathrm{ml}$ castor oil and placed in the cages and observed for the defecation. ${ }^{19}$

\section{Small intestinal transit model}

The mice of weight $20-25 \mathrm{~g}$ were divided in to the four groups with four animals in each group and were housed in labeled cages. Animals were given a period of time to adjust to the new environment provided with food and water. Group I Animal were administered the $0.1 \mathrm{ml}$ saline. Group II Animals received the reference standard drug Atropine sulphate ( $5 \mathrm{mg} / \mathrm{kg}$ body weight). Group III Animals were given ethanolic extract of Helianthus annuus L. at dose of $250 \mathrm{mg} / \mathrm{kg}$ body weight. Group IV Animals were given ethanolic extract of Helianthus annuus L. at dose of $500 \mathrm{mg} / \mathrm{kg}$ body weight. They were fasted for 24 hours prior to the test, but were allowed free access to water. Thirty minutes after drug administration, $1 \mathrm{ml}$ of charcoal meal (5\% activated charcoal in $10 \%$ aqueous tragacanth) was administered to all the animals in the study and thirty minutes later, all the rats were sacrificed and the abdomen opened. The small intestine was dissected out and the distance covered by the charcoal meal in the small intestine from the pylorus to the caecum was measured and expressed as a percentage of the distance traveled. ${ }^{20}$

\section{Histamine induced bronchospasm in guinea pigs}

The guinea pigs were fasted overnight and were divided into four groups with four animals in each group. They were exposed to aerosol of $0.1 \%$ Histamine using nebulizer with constant pressure $160 \mathrm{~mm} / \mathrm{Hg}$ in histamine chamber and time for pre convulsion dyspnoea was recorded from the time of aerosol exposure to the onset of dyspnoea leading to the appearance of asphyctic convulsions i.e. pre-convulsion time. As soon as pre convulsion dyspnoea commenced, animals were removed from the chamber and placed in fresh air to recover for 24 hours. After 24 hours the Group I serve as control and receive distilled water. Group II received chlorpheniramine maleate $(2 \mathrm{mg} / \mathrm{kg})$ and served as standard. Group III and IV received the ethanolic extract at the doses of 250 and $500 \mathrm{mg} / \mathrm{kg}$ respectively. These animals were again exposed to Histamine aerosol later at $4 \mathrm{~h}$ and $24 \mathrm{~h}$ to determine pre convulsion dyspnoea. ${ }^{21}$ The percentage protection offered by the treatment was calculated by the following formula,

$$
\% \text { Protection }=\{1-\mathrm{T} 1 / \mathrm{T} 2\} \times 100
$$

Where, $\mathrm{T} 1=$ time in second for pre convulsion dyspnoea before treatment; $\mathrm{T} 2$ = time in second for pre convulsion dyspnoea after treatment

\section{Microshock in rabbit model}

In this model rabbits in place of gunia pig were utilized. The rabbits were fasted overnight and groups which were previously defined in histamine induced bronchospasm, were exposed to aerosol of $0.2 \%$ histamine using nebulizer with constant pressure $160 \mathrm{~mm} / \mathrm{Hg}$ in histamine chamber and time for pre convulsion dyspnoea was recorded from the time of aerosol exposure to the onset of dyspnoea leading to the appearance of asphyctic convulsions i.e., pre-convulsion time. With the procedure defined above, after 24 hours the Group I serve as control and receive distilled water. Group II received chlorpheniramine maleate $(2 \mathrm{mg} / \mathrm{kg})$ and served as standard. Group III and IV received the ethanolic extract at the doses of 250 and $500 \mathrm{mg} / \mathrm{kg}$ respectively. These animals were again exposed to Histamine aerosol later at $4 \mathrm{~h}$ and $24 \mathrm{~h}$ to determine pre convulsion dyspnoea. ${ }^{22}$ The percentage protection offered by the treatment was calculated by the following formula;

$$
\% \text { Protection }=\{1-\mathrm{T} 1 / \mathrm{T} 2\} \times 100
$$

Where, $\mathrm{T} 1=$ time in second for pre convulsion dyspnoea before treatment; $\mathrm{T} 2$ = time in second for pre convulsion dyspnoea after treatment

These animal studies were carried out after obtaining the approval of the Institute's Animal Ethics Committee (approval code no. 005/2009/CPCSEA/JNU). 


\section{Statistical analysis}

All values are expressed as mean \pm SEM. Statistical analysis was performed by one-way analysis of variance (ANOVA) followed by Dunnett's tests using Graphpad Prizm 6 software. The results were considered statistically significant if probability factor, $\mathrm{P}<0.05 .^{23}$

\section{RESULTS AND DISCUSSION}

After the extraction, the \% yield was found to be $3.82 \%$. The phytochemical screening of extract of Helianthus annuus L. showed the presence of carbohydrates, glycosides, saponins and alkaloids. The presence of phenolic and other flavonoid contents was also confirmed which are one of the most essential phytochemicals to possess the activity.

\section{In-vitro antioxidant activity using DPPH as standard}

Absorbance of DPPH at $517 \mathrm{~nm}$ was 1.4908 and percentage inhibition was calculated on this absorbance by comparing extract with ascorbic acid. ANOVA was applied to the results by using Graphpad prizm 6 Software. P value is $<0.0001$ which shows that the results are significant to that of control.

Table 1: Free radical scavenging activity of ascorbic acid and extract

\begin{tabular}{|c|c|c|c|c|}
\hline Concentration $(\boldsymbol{\mu g} / \mathbf{m l})$ & $\begin{array}{c}\text { Absorbance for Ascorbic } \\
\text { Acid }\end{array}$ & $\begin{array}{c}\text { \% Inhibition by Ascorbic } \\
\text { acid }\end{array}$ & $\begin{array}{c}\text { Absorbance for Extract } \\
\text { Inhibition by Extract }\end{array}$ & 0.3321 \\
\hline 5 & 0.4458 & 70.09 & 37.48 \\
\hline 10 & 0.3983 & 73.28 & 0.2142 \\
\hline 50 & 0.2898 & 80.56 & 0.1532 \\
\hline 100 & 0.1498 & 89.52 & 0.0993 \\
\hline 200 & 0.0987 & 93.38 & 0.0332 \\
\hline 500 & 0.0505 & 96.61 & 0.0133 & \\
\hline
\end{tabular}

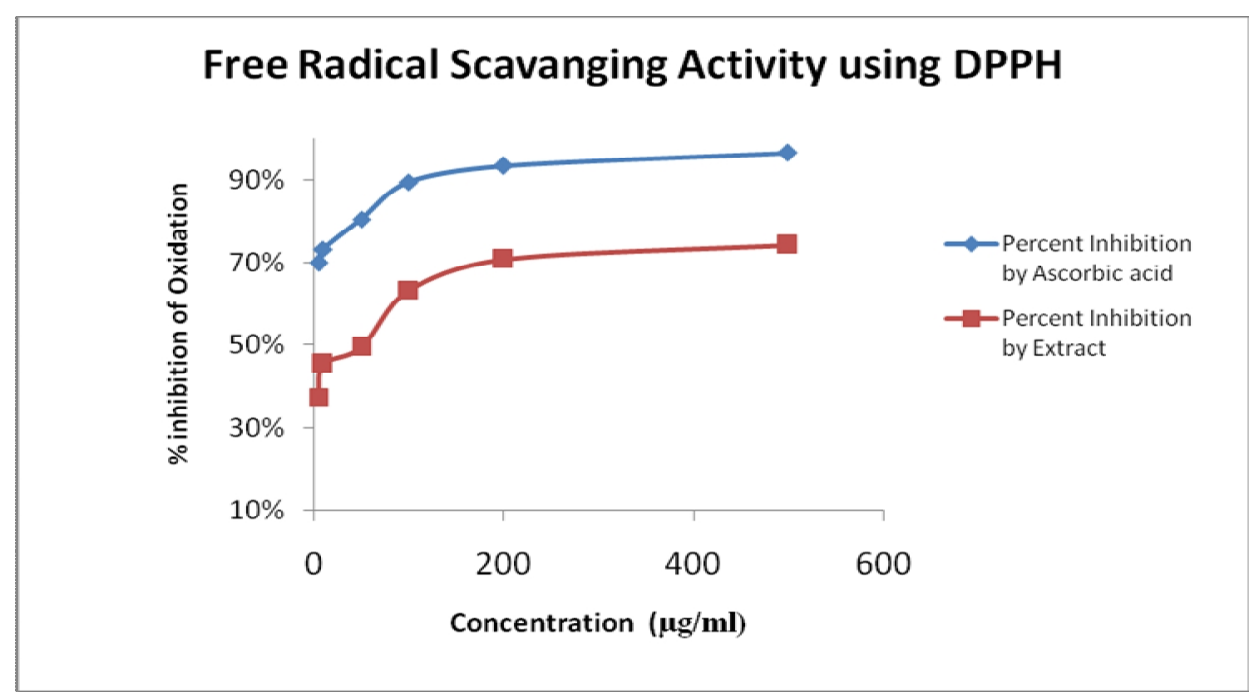

Figure 1: Free radical scavenging activity of ascorbic acid and ethanolic extract of Helianthus annuus $\mathbf{L}$

\section{Castor oil induced diarrhea model}

Table 2: Effect of Helianthus annuus extract on castor oil induced diarrhea in experimental mice, where $n=4$

\begin{tabular}{|c|c|c|c|c|}
\hline Group & $\begin{array}{c}\text { Dose } \\
(\mathbf{m g} / \mathbf{k g})\end{array}$ & $\begin{array}{c}\text { Onset of time } \\
\text { (minutes) }\end{array}$ & $\begin{array}{c}\text { Total weight of fecal } \\
\text { matter (g) }\end{array}$ & \% Reduction \\
\hline Group I (Control) & - & $32.95 \pm 2.20$ & $0.357 \pm 0.03$ & 0.00 \\
\hline Group II (Standard) & 3 & $89.79 \pm 2.55$ & $0.104 \pm 0.01$ & 76.71 \\
\hline Group III (Extract) & 250 & $40.29 \pm 1.54$ & $0.139 \pm 0.03$ & 42.15 \\
\hline Group IV (Extract) & 500 & $74.75 \pm 2.12$ & $0.137 \pm 0.01$ & 67.01 \\
\hline
\end{tabular}




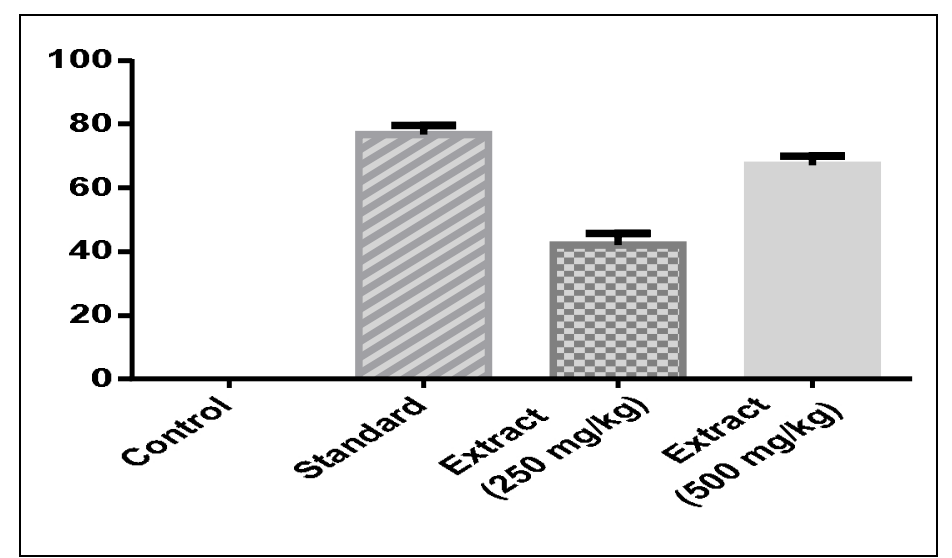

Figure 2: Graphical presentation of one way ANOVA using Graphpad prizm 6 software

In castor oil induced diarrheal model, the ethanolic extract of leaves of Helianthus annuus L. at the doses of 250 $\mathrm{mg} / \mathrm{kg}$ and $500 \mathrm{mg} / \mathrm{kg}$ has showed the significant inhibition in the fecal matter in experimental mice with $\mathrm{p}$ value is $<0.001$. The ethanolic extract of Helianthus annuus L. at dose of $500 \mathrm{mg} / \mathrm{kg}$ has showed the significant decrease in the fecal matter in comparison with the standard drug loperamide (3 $\mathrm{mg} / \mathrm{kg})$. The corresponding decrease in fecal matter was $42.15 \%$ and $67.01 \%$ respectively for $250 \mathrm{mg} / \mathrm{kg}$ and $500 \mathrm{mg} / \mathrm{kg}$ body weight.

\section{Small intestinal transit model}

Table 3: Small intestinal transit model in experimental mice, where $n=4$

\begin{tabular}{|c|c|c|c|}
\hline Group & $\begin{array}{c}\text { Dose } \\
(\mathbf{m g} / \mathbf{k g})\end{array}$ & Mean distance $(\mathbf{c m} \pm \mathbf{S D})$ & \% Reduction \\
\hline Group I (Control) & - & $27.90 \pm 1.49$ & $0.00 \%$ \\
\hline Group II (Standard) & 5 & $7.58 \pm 0.80$ & $72.40 \%$ \\
\hline Group III (Extract) & 250 & $21.18 \pm 1.47$ & $27.59 \%$ \\
\hline Group IV (Extract) & 500 & $14.33 \pm 1.28$ & $48.62 \%$ \\
\hline
\end{tabular}

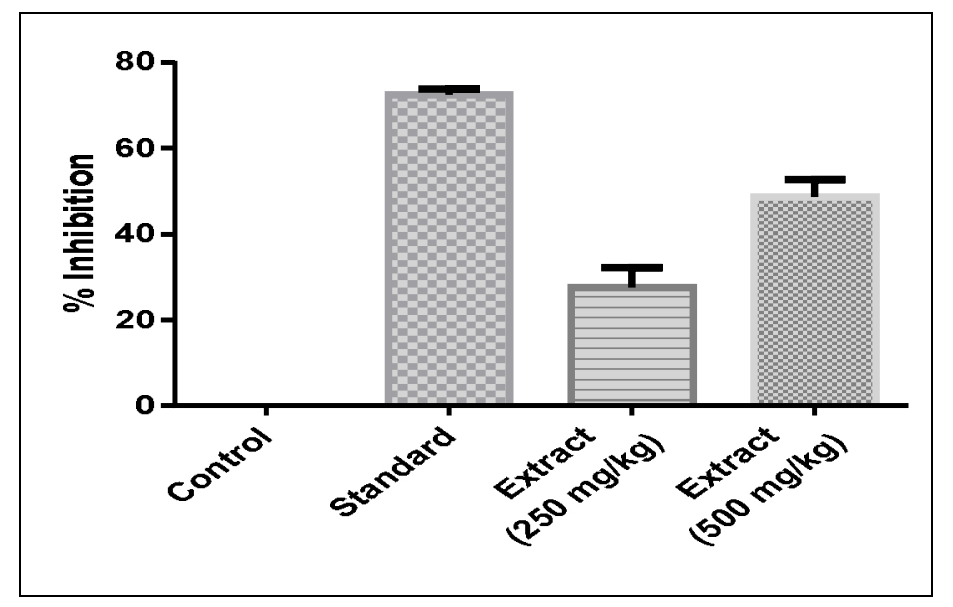

Figure 3: Graphical presentation of one way ANOVA using Graphpad prizm 6 software

In small intestinal transit model, the ethanolic extract of Helianthus annuus L. at the dose of $250 \mathrm{mg} / \mathrm{kg}$ and 500 $\mathrm{mg} / \mathrm{kg}$ decreased the intestinal transit. The greater inhibitory effect against the charcoal meal was seen at the dose of $500 \mathrm{mg} / \mathrm{kg}$ of body weight in comparison to that of control with $\mathrm{p}$ value $<0.001$ which is considered to be significant. The effect was compared with the $5 \mathrm{mg} / \mathrm{kg}$ dose of atropine sulphate. The corresponding reduction was $27.59 \%$ and $48.62 \%$ respectively for the $250 \mathrm{mg} / \mathrm{kg}$ and $500 \mathrm{mg} / \mathrm{kg}$ body weight. 
Histamine induced bronchocontriction in guinea pigs

Table 4: Histamine induced bronchocontriction in guinea pigs, where $n=4$

\begin{tabular}{|c|c|c|c|}
\hline \multirow{2}{*}{ Group } & \multirow{2}{*}{ Dose (mg/kg) } & \multicolumn{2}{|c|}{ Pre convulsive dyspnea } \\
\cline { 3 - 4 } & & $\mathbf{4} \mathbf{~ h}$ & $\mathbf{2 4} \mathbf{~ h}$ \\
\hline Group I (Control) & - & $55.10 \pm 1.06$ & $57.26 \pm 0.97$ \\
\hline Group II (Standard) & 2 & $188.26 \pm 1.47$ & $143.26 \pm 0.88$ \\
\hline Group III (Extract) & 250 & $102.79 \pm 1.32$ & $94.58 \pm 1.69$ \\
\hline Group IV (Extract) & 500 & $144.77 \pm 1.22$ & $114.29 \pm 0.86$ \\
\hline
\end{tabular}

Table 5: Percentage protection against histamine induced bronchocontriction in guinea pigs at different time interval, where $n=4$

\begin{tabular}{|c|c|c|c|}
\hline \multirow{2}{*}{ Group } & Dose (mg/kg) & \multicolumn{2}{|c|}{ Percentage protection } \\
\cline { 3 - 4 } & & $\mathbf{4} \mathbf{~ h}$ & $\mathbf{2 4} \mathbf{~ h}$ \\
\hline Group I (Control) & - & - & - \\
\hline Group II (Standard) & 2 & $70.73 \%$ & $60.02 \%$ \\
\hline Group III (Extract) & 250 & $46.54 \%$ & $39.55 \%$ \\
\hline Group IV (Extract) & 500 & $62.15 \%$ & $49.88 \%$ \\
\hline
\end{tabular}

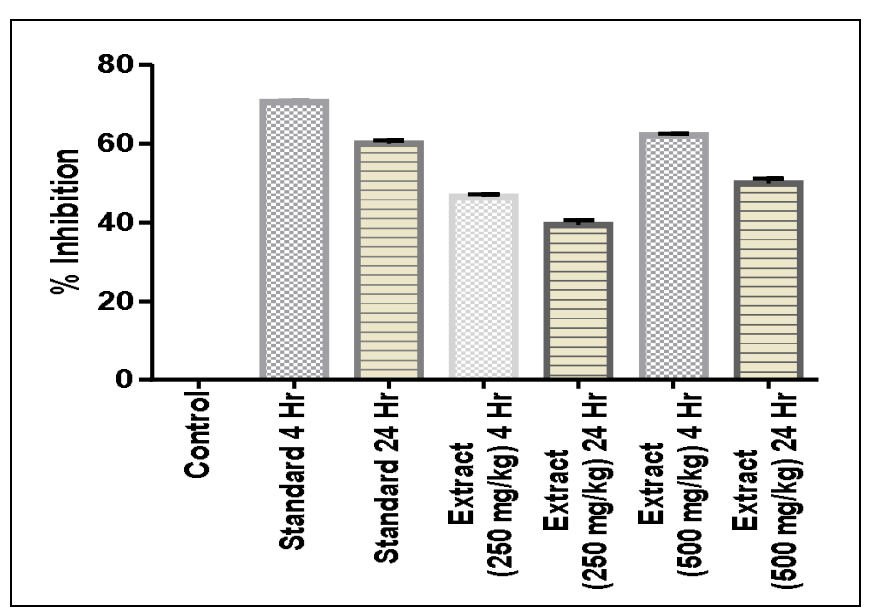

Figure 4: Graphical presentation of one way ANOVA using Graphpad prizm 6 software

In the present study, the guinea pigs were exposed to the $0.1 \%$ of histamine aerosol which showed the sign of progressive dyspnoea leading to convulsion. The chlorphenamine maleate significantly prolong the latent period of convulsions. The ethanolic extract showed significant results when compare to the standard $(\mathrm{p}<$ $0.0001)$. The percent protection was found to be $46.54 \%$ and $62.15 \%$ after 4 hours at the doses of $250 \mathrm{mg} / \mathrm{kg}$ and $500 \mathrm{mg} / \mathrm{kg}$ respectively.

\section{Micro shock method on rabbit}

Table 6: Histamine induced bronchoconstriction in rabbits, where $n=4$

\begin{tabular}{|c|c|c|c|}
\hline \multirow{2}{*}{ Group } & \multirow{2}{*}{$\begin{array}{c}\text { Dose } \\
\text { (mg/ } \mathbf{k g})\end{array}$} & \multicolumn{2}{|c|}{ Pre convulsive dyspnea } \\
\cline { 3 - 4 } & - & $\mathbf{4} \mathbf{~ h}$ & $\mathbf{2 4} \mathbf{~ h}$ \\
\hline Group I (Control) & - & $55.10 \pm 1.06$ & $57.26 \pm 0.97$ \\
\hline Group II (Standard) & 2 & $188.26 \pm 1.47$ & $143.26 \pm 0.88$ \\
\hline Group III (Extract) & 250 & $102.79 \pm 1.32$ & $94.58 \pm 1.69$ \\
\hline Group IV (Extract) & 500 & $144.77 \pm 1.22$ & $114.29 \pm 0.86$ \\
\hline
\end{tabular}

Table 7: Percentage protection against histamine induced bronchoconstriction in rabbits at different, where $n=4$

\begin{tabular}{|c|c|c|c|}
\hline Group & \multirow{2}{*}{$\begin{array}{c}\text { Dose } \\
\text { (mg/kg) }\end{array}$} & \multicolumn{2}{|c|}{ Percentage protection } \\
\cline { 3 - 4 } & $\mathbf{4} \mathbf{~ h}$ & $\mathbf{2 4} \mathbf{~ h}$ \\
\hline Group I (Control) & - & - & - \\
\hline Group II (Standard) & 2 & $72.14 \%$ & $53.22 \%$ \\
\hline Group III (Extract) & 250 & $52.55 \%$ & $25.43 \%$ \\
\hline Group IV (Extract) & 500 & $70.69 \%$ & $41.65 \%$ \\
\hline
\end{tabular}




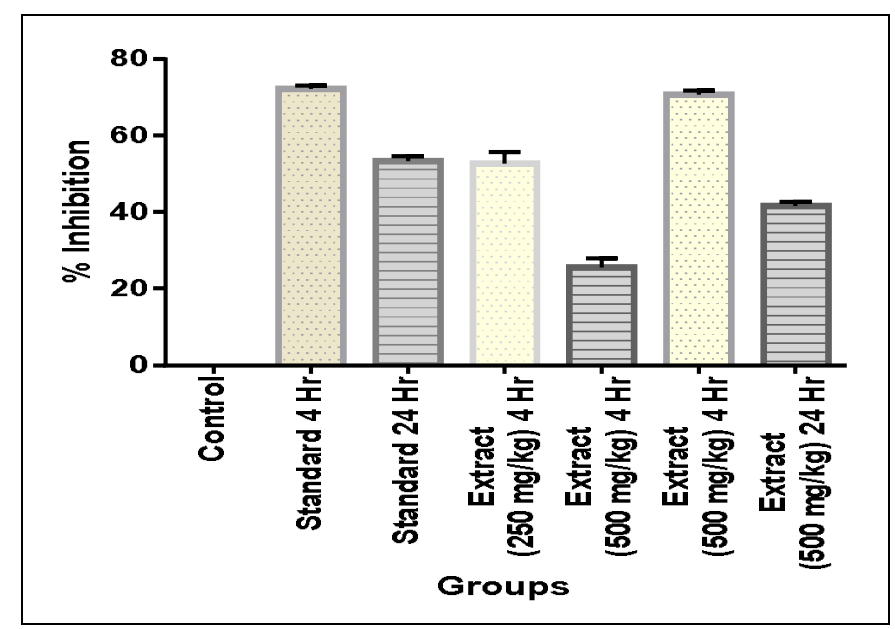

Figure 5: Graphical presentation of one way ANOVA using Graphpad prizm 6 software

In the present study, the rabbit were exposed to the $0.2 \%$ of histamine aerosol which showed the sign of progressive dyspnoea leading to convulsion. The chlorphenamine maleate significantly protected prolonged the latent period of convulsions. The ethanolic extract showed significant protection $(\mathrm{p}<0.001)$. The percent protection was found to be $52.55 \%$ and $70.69 \%$ after $4 \mathrm{~h}$ at the doses of $250 \mathrm{mg} / \mathrm{kg}$ and $500 \mathrm{mg} / \mathrm{kg}$ respectively.

\section{CONCLUSION}

In present study, the leaves part of Helianthus annuus L. were evaluated for its anti diarrheal activity by castor oil induced diarrheal model, small intestinal transit model and antihistaminic activity by histamine induced bronchoconstriction in guinea pigs and rabbits. The significant results were observed in which ethanolic extract showed the marked decrease in the total volume of the fecal matter and acted by increasing the reabsorption of electrolyte and water for antidiarrheal activity and significantly prolonged the pre convulsive time as compared to the control in guinea pigs and rabbits. Leaves were also confirmed for its antioxidant activity. The presence of phenols and flavonoids are responsible for these activities. Sunflower, the heliotropism plant can further be evaluated for active constituents responsible for these activities and utilized for different asthmatic or inflammatory disease treatment and as antidiarrheal herb.

\section{REFERENCES}

1. Dwivedi A, Sharma GN. A review on heliotropism plant: Helianthus annuus L. The journal of phytopharmacology 2014; 3(2): 149-155.

2. Subashini R, Rakshitha SU. Phytochemical screening, antimicrobial activity and in vitro antioxidant investigation of methanolic extract of seeds from Helianthus annuus L. Chemical science review and letters 2012; 1(1): 30-34.

3. Kamal J. Quantification of alkaloids, phenols and flavonoids in sunflower (Helianthus aпnиus L.). African Journal of Biotechnology 2011; 10(16): 3149-3151.

4. Fiska ID, Whitea DA, Carvalhob A, Graya DA. Tocopherol - an intrinsic component of sunflower seed oil bodies. Journal of the American oil chemists' society 2006; 83(4): 341-344. http://dx.doi.org/10.1007/s11746-006-1210-2

5. Saini S, Sharma S. Antidiabetic effect of Helianthus annuus L., seeds ethanolic extract in streptozotocin nicotinamide induced type-2 diabetes mellitus. International Journal of Pharmacy and Pharmaceutical Sciences 2013; 5(2): 382-387.

6. Ukiya M, Akihisa T, Tokuda H, Koike K, Takayasu J, Okuda H, Kimura Y, Nikaido T, Nishino H. Isolation, structural elucidation and inhibitory effects of terpenoid and lipid constituents from sunflower pollen on epstein-barr virus early antigen induced by tumor promoter, TPA. Journal of agricultural and food chemistry 2003; 51(10): 2949-57. http://dx.doi.org/10.1021/jf0211231

7. Nadeem M, Anjum FM, Hussain S, Khan MR, Shabbir MA. Assessment of the antioxidant activity and total phenolic contents of sunflower hybrids. Pak. J. Food Sci 2011; 24(1-4): 7-12.

8. Heo JC, Woo SU, Kweon MA, Park JY, Lee HK, Son M, Rho JR, Lee SH. Aqueous extract of the Helianthus annuus seed alleviates asthmatic symptoms in vivo. International Journal of Molecular Medicine 2008; 21(1): 57-61.

9. Ukiya M, Akihisa T, Yusukawa K, Takahashi A, Suzuki T, Kimura Y. Triterpene glycosides from the flower petals of sunflower (Helianthus annuus) and their anti-inflammatory activity. Journal of natural products 2007; 70(5): 813-816. http://dx.doi.org/10.1021/np0780021

10. Sen M, Bhattacharyya DK. Hypolipidemic effect of enzymatically extracted sunflower seed protein fraction. Journal of the science of food and agriculture 2001; 81(3): 347-352. http://dx.doi.org/ 10.1002/1097-0010(200102)81:3<347::AID-JSFA812>3.0.CO;2-8

11. Sankaranarayanan S, Bama P, Deccaraman M, Vijayalakshimi M, Murugesan K, Kalaichelvan PT, Arumugam P. Isolation and characterization of bioactive and antibacterial compound from Helianthus annuus L. Indian J Exp Biol 2008; 46(12): 831-835.

12. Tripathi KD. Essential of medical pharmacology. $6^{\text {th }}$ ed, Jaypee Brothers Medical Publishers; 2008. p. 1-917. http://dx.doi.o $\mathrm{rg} / 10.5005 / \mathrm{jp} / \mathrm{books} / 10282$

13. Krystal AD, Richelson E, Roth T. Review of the histamine system and the clinical effects of $\mathrm{H} 1$ antagonists: basis for a new model for understanding the effects of insomnia medications. Sleep medical reviews 2013; 17(4): 263-272. http://dx.doi.org/ 10.1016/j.smrv.2012.08.001

14. Subashini R, Umamaheswari SR. Phytochemical screening, antimicrobial activity and in vitro antioxidant investigation of methanolic extract of seeds from Helianthus annuus L. Chemical science review and letters 2012;1(1): 30-34.

15. Javed K. Quantification of alkaloids, phenols and flavonoids in sunflower (Helianthus annuи L.). African Journal of Biotechnology 2001; 10(16): 3149-3151.

16. Adetunj CO, Olatunji OM, Ogunkunle ATJ, Adetunji JB, Ogundare MO. Antimicrobial activity of ethanolic extract of Helianthus annuus stem. SMU Medical Journal 2014; 1(1): 79-88.

17. Iyengar MA. Study of crude drugs. Manipal power press 1995; 8: 2 .

18. Asadujjaman M, Hossain AM, Karmakar UK. Assessment of DPPH free radical scavenging activity of some medicinal. Pharmacology online 2013; 1: 161-165.

19. Rao V, Madhavan V, Sairam K, Vikas K. Antidiarrhoeal activity of the Cinnamomum tamala in experimental rats. Journal of natural 
medicine 2008; 62: 396-402. http://dx.doi.org/10.1007/s11418008-0258-8

20. Akuodor GC, Muazzam I, Usman Idris M, Megwas UA, Akpan JL, Chilaka KC, Okoroafor DO, Osunkwo UA. Evaluation of the anti diarrheal activity of methanol leaf extract of Bombax buonopozense in rats. Ibnsona Journal of Medicine and Biomedical Sciences 2011;3(1): 15-20

21. Suralkar A, Jadhav A, Vaidhya G, Gaikwad K. Anti-histaminic and broncho dilating activity of fruit berries of Embella ribes. Int. Res. J. Pharm 2012; 3(10): 182-184.

22. Gupta SK. Drug screening methods. $1^{\text {sted, Jaypee Brother }}$ Medical Publishers Ltd; 2004. p. 1-495. http://dx.doi.org/ $10.5005 / \mathrm{jp} /$ books $/ 10243$
23. Azi LH, Eric BG, Donatus AW, Agyei AF, Eric W Antinociceptive activity of various solvent extracts of Maerua angolensis dc stem bark in rodents. The Journal of phytopharmacology 2014; 3(1): 1-8.

\section{Cite this article as:}

Dwivedi A, Sharma GN, Kaushik AY. Evaluation of Helianthus annuus L. leaves extract for the antidiarrheal and antihistaminic activity. Int. J. Res. Ayurveda Pharm. 2015;6(1):118-123 http://dx.doi.org/10.7897 /2277-4343.06125

Source of support: Nil, Conflict of interest: None Declared 